Agroradix Vol. 3 No.2

ISSN : 2621-0665

\title{
ISOLASI DAN UII SINERGISME BAKTERI ENDOFIT TANAMAN PADI (Oryza sativa L.) UNTUK KONSORSIUM BIOFERTILIZER
}

\author{
Dyah Ayu Sri Hartanti \\ Fakultas Pertanian, Universitas KH. A. Wahab Hasbullah, Jombang, Jawa Timur \\ Korespondensi: adyah674@yahoo.com
}

\begin{abstract}
ABSTRAK
Bakteri endofit adalah bakteri yang terdapat pada jaringan tanaman, yang mempunyai beberapa peran untuk mendukung pertumbuhan tanaman dengan membantu menyediakan unsur hara. Pada hasil penelitian ini didapatkan empat isolat bakteri endofit yaitu EPS1, EPS2, EPS3, dan EPS4 yang masing-masing adalah genus dari Pseudomonas, Bacillus, Enterobacter, dan Azotobacter. Dilakukan uji sinergisme dari isolat yang didapatkan, uji ini dilakukan secara kualitatif menggunakan dua metode yaitu metode streak dan paper disc dengan melihat ada tidaknya zona hambat atau zona bening pada media pertumbuhan yang digunakan. Pada metode streak isolat EPS4 dilihat sifat sinerginya terhadap isolat EPS1, EPS2, dan EPS3. Sedangkan metode yang menggunakan paper disc isolat EPS2 dilihat sifat sinerginya terhadap isolat EPS1, EPS3, dan EPS4. Hasil uji sinergisme setelah dilakukan inkubasi selama 24 jam menunjukkan bahwa masing-masing isolat yang bersinggungan tidak membentuk zona bening atau zona hambat, hal ini menunjukkan sifat kompatibilitas untuk menjadikan isolat bakteri endofit ini sebagai konsorsium biofertilizer.
\end{abstract}

Kata kunci : Isolasi, Bakteri endofit, Sinergisme, Konsorsium

\section{ABSTRACT}

Endophytic bacteria are bacteria found in plant tissues, which have several roles to support plant growth by helping to provide nutrients. In the results of this study, four endophytic bacterial isolates were found, namely EPS1, EPS2, EPS3, and EPS4, each of which were genera of Pseudomonas, Bacillus, Enterobacter, and Azotobacter. Synergism test was carried out from the isolates obtained, this test was carried out qualitatively using two methods namely the streak method and paper disc method. Synergism test by looking at the presence or absence of inhibition zones or clear zones on the growth media used. In the EPS isolate streak method seen the synergistic nature of isolates EPS1, EPS2, and EPS3. While the method that uses EPS2 paper disc isolates is seen the synergistic nature of EPS1, EPS3, and EPS4 isolates. Synergism test results after 24 hours of incubation showed that each isolate that intersected did not form a clear zone or inhibitory zone, this shows the compatibility properties to make this endophytic bacterial isolate a biofertilizer consortium.

Key words: Isolation, Endophitic Bacteria, Synergism, Consortium

\section{PENDAHULUAN}

Faktor yang menentukan pertumbuhan tanaman salah satunya adalah tanah. Tanah adalah media pertumbuhan tanaman yang didalamnya mengandung nutrisi atau zat hara mineral yang menjadi salah sau indikator kesuburan tanah. Beberapa kegiatan manusia yang tidak memedulikan lingkungan khususnya tanah sebagai tempat tumbuh dan berkembangnya tanaman dapat menyebabkan menurunnya kualitas tanah. Salah satu kegiatan yang mempengaruhi kualitas tanah yaitu pemberian pupuk sintetis yang tidak 
Agroradix Vol. 3 No.2

ISSN : 2621-0665

memerhatikan dosis dan frekuensi pupuk sintetis tersebut untuk mendapatkan produktivitas hasil pertanian yang tinggi. Pemberian pupuk sintetis yang tidak memerhatikan dosis dan dilakukan secara terus menerus dapat menyebabkan perubahan tanah secara fisika, biologi, dan kimia, serta peranan pupuk sintetis tidak dapat memperbaiki kualitas tanah yang menurun, namun hanya menyumbang unsur hara tanah (Nurmayulis, 2005).

Cara untuk meminimalisir pemberian pupuk sintetis pada lahan pertanian dan memperbaiki kualitas tanah yang mulai menurun yaitu menggunakan agen hayati yang terdapat didalam tanah yang disebut dengan bakteri tanah. Bakteri yang ada di dalam tanah dapat melakukan migrasi kedalam jaringan tanaman dan mampu mendukung pertumbuhan tanaman disebut sebagai bakteri endofit (Saraswati et al, 2004).

Bakteri endofit masuk kedalam jaringan tanaman melalui beberapa organ tanaman misalnya buah, batang, biji, jaringan pembuluh, namun paling umum yang menjadi tempat kolonisasi bakteri endofit yaitu akar (Simarmata dkk, 2007), hal ini kemungkinan karena akar adalah organ yang langsung berinteraksi dengan tanah, sehingga bakteri yang berada di dalam tanah dapat melakukan migrasi kedalam jaringan tanaman.

Bakteri endofit dapat memproduksi senyawa biologis atau menghasilkan metabolit sekunder, salah satunya adalah hormon Indole Acetic Acid (IAA), hormon ini berperan dalam membantu pertumbuhan tanaman. Peningkatan pertumbuhan tanaman oleh bakteri endofit dapat terjadi karena mekanisme pengikatan nitrogen di udara, memproduksi beberapa hormon tanaman yaitu sitokinin dan giberelin (Thakuria et al, 2004).

\begin{tabular}{llr}
\multicolumn{2}{c}{ Beberapa bakteri } & endofit yang \\
berpotensi & untuk & mendukung \\
pertumbuhan & dapat dijadikan suatu \\
konsorsium & untuk & biofertilizer. \\
Pemanfaatan & konsorsium mikroba
\end{tabular}
cenderung memberikan hasil yang lebih baik jika dibandingkan dengan pemberian isolat tunggal yang di aplikasikan pada tanaman, hal ini disebabkan karena tiap jenis mikroba dapat menghasilkan metabolit sekunder atau enzim yang dapat saling melengkapi untuk pertumbuhan mikroba satu dengan yang lain (Siahaan et al, 2103). Adanya kesesuaian atau kecocokan antara bakteri satu dengan yang lain sangat diperlukan untuk dijadikan konsorsium. Penelitian ini bertujuan untuk melakukan isolasi bakteri endofit dan uji sinergisme bakteri endofit yang berhasil diisolasi yang dapat digunakan sebagai konsorsium biofertilizer.

\section{METODE PENELITIAN}

\section{Bahan dan Alat}

Peralatan yang digunakan dalam penelitian ini yaitu autoklaf, timbangan analitik, pinset, jarum ose, mikroskop, mortar, alu, erlenmeyer glass, pipet volume, cawan petri, tabung reaksi, mikropipet dan paper disc.

Bahan yang digunakan adalah akar padi varietas situbagendit yang berumur 45 hari, akuades steril, bahan kimia yaitu etanol $75 \%$, sodium hipoklorit $5 \%$, Nutrient Agar (Oxoid), Nutrient Broth (Oxoid), kristal violet, safranin, dan iodium.

\section{Rancangan Penelitian}

Penelitian ini adalah jenis penelitian ekploratif pada tahap isolasi bakteri endofit dan uji sinergisme bakteri endofit.

\section{Metode Analisis}

Analisis hasil penelitian ini baik tahap isolasi dan identifikasi bakteri endofit, serta uji sinergisme bakteri endofit dianalisis secara deskriptif kualitatif (Nautiyal, 1999). 
Agroradix Vol. 3 No.2

ISSN : 2621-0665

\section{Tahapan Penelitian \\ Isolasi Bakteri Endofit}

Sampel akar tanaman padi diambil secara random dari lahan pertanian Kecamatan Tikung, Kabupaten Lamongan. Varietas tanaman padi yang digunakan adalah varietas situbagendit yang berumur 45 hari. Akar yang didapatkan ditimbang sebanyak 10 gram, lalu dicuci bersih menggunakan air mengalir. Tahap pertama dalam melakukan isolasi bakteri endofit yaitu melakukan sterilisasi permukaan akar terlebih dahulu dengan melakukan perendaman pada larutan etanol $75 \%$ selama tiga menit, kemudian selama lima menit akar direndam pada larutan sodium hipoklorit, setelah itu dilakukan pembilasan sebanyak lima kali pada aquades steril (Mbai et al, 2013).

Akar yang steril dihaluskan kemudian dilakukan pengenceran dengan memasukkan akar kedalam Erlenmeyer yang berisi $90 \mathrm{ml}$ akuades steril kemudian $1 \mathrm{ml}$ suspensi dimasukkan kedalam tabung reaksi yang berisi $9 \mathrm{ml}$ akuades steril, pengenceran dilakukan hingga pengenceran $10^{-3}$. Hasil pengenceran diinokulasikan secara pour plate di media NA dan dilakukan perhitungan jumlah koloni yang dinyatakan dalam CFU (Colony Forming Units) setelah masa inkubasi 3-5 hari di inkubator dengan suhu $30^{\circ} \mathrm{C}$. Dilakukan perhitungan bakteri yang tumbuh dan dilakukan pengelompokkan bakteri berdasarkan pengamatan bentuk koloni, elevasi koloni, permukaan koloni dan warna koloni. Koloni bakteri yang terpilih di identifikasi secara makroskopis, mikroskopis dan dilakukan uji fisiologis (Etesami et al., 2014). Pengamatan secara mikroskopis didukung dengan melakukan pewarnaan gram bakteri. Uji fisiologis sangat dibutuhkan dalam proses identifikasi bakteri yang berhasil diisolasi (Etesami et al., 2014).

\section{Uji Sinergisme Bakteri Endofit}

Uji sinergisme pada penelitian ini dilakukan secara kualitatif dengan mengamati adanya zona bening atau zona hambat yang terbentuk jika bakteri endofit yang diujikan tidak kompatibel Pada uji sinergisme bakteri endofit yang berhasil diisolasi dan telah berhasil diidentifikasi terdapat dua metode yang digunakan yaitu metode streak dan metode menggunakan paper disc.

Pada metode streak masingmasing isolat digoreskan bersinggungan satu sama lain menggunakan metode gores pada cawan petri yang berisi media NA sehingga antar isolat akan bertemu. Dilakukan inkubasi pada incubator di suhu $30^{\circ} \mathrm{C}$ selama 24 jam dan diamati adanya zona bening atau zona hambat diantara dua isolat yang bersinggungan. Isolat dikatakan kompatibel jika tidak terdapat zona penghambatan pada daerah pertemuan kedua isolat, dan dikatakan tidak kompatibel apabila terdapat zona penghambatan pada daerah pertemuan kedua isolat tersebut (Asri dan Zulaikah, 2016). Metode lain yang digunakan untuk menunjang uji sinegisme antar isolat bakteri, yaitu suspensi bakteri dibuat dengan standar Mac Farland $\left(10^{8} \mathrm{CFU} / \mathrm{mL}\right)$, kemudian suspensi bakteri dioleskan di permukaan media NA dengan cutton bud. Pada media NA paper disc diletakkan dan ditetesi dengan suspensi bakteri lain sebanyak $10 \mu \mathrm{m}$, lalu diinkubasi pada suhu ruang selama 2 hari. Isolat yang bersifat sinergis ditunjukkan dengan tidak adanya zona hambat yang terbentuk (Silitonga, dkk., 2008).

\section{HASIL DAN PEMBAHASAN}

\section{Hasil Isolasi Bakteri Endofit}

Dari hasil isolasi dan identifikasi bakteri endofit akar tanaman padi varietas situ bagendit diperoleh 4 jenis isolat bakteri endofit (Gambar 1). Karakteristik masing-masing isolat disajikan pada Tabel 1. 
Agroradix Vol. 3 No.2

ISSN : 2621-0665

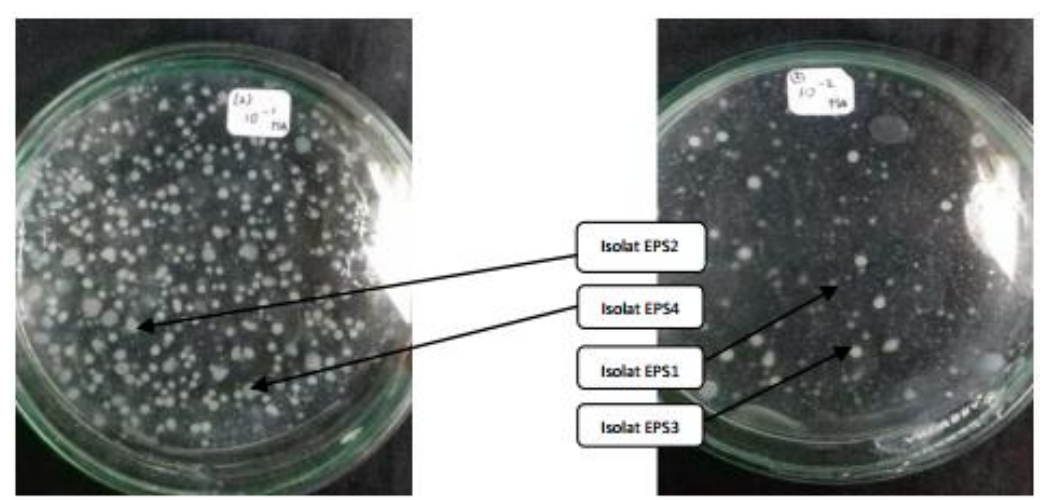

Gambar 1. Hasil isolasi bakteri endofit akar tanaman padi varietas situbagendit

Tabel 1. Karakteristik makroskopis isolat bakteri endofit dari akar tanaman padi varietas situ bagendit

\begin{tabular}{ccccc}
\hline \multirow{2}{*}{ Isolat Bakteri } & \multicolumn{4}{c}{ Morfologi Isolat } \\
\cline { 2 - 5 } & Bentuk Koloni & Warna Koloni & Elevasi Koloni & $\begin{array}{c}\text { Permukaan } \\
\text { Koloni }\end{array}$ \\
\hline EPS1 & Bulat & Krem & Conveks & Halus \\
EPS2 & Irregular & Krem & Conveks & Halus \\
EPS3 & Bulat & Bening & Conveks & Halus \\
EPS4 & Bulat & Krem & Raised & Halus \\
\hline
\end{tabular}

$\begin{array}{lll}\text { Keempat isolat bakteri yang } & \text { conveks (cembung), permukaan keempat } \\ \text { berhasil diisolasi dan diidentifikasi } & \text { koloni halus. Setelah dilakukan } \\ \text { dilakukan berdasarkan kesamaan secara } & \text { pengamatan secara makroskopis, } \\ \text { makroskopis. Secara makroskopis, bentuk } & \text { selanjutnya dilakukan pengamatan secara } \\ \text { koloni bakteri didominasi bentuk bulat dan } & \text { mikroskopis. Hasil pengamatan } \\ \text { warna koloni krem, elevasi koloni } & \text { mikroskopis dan pewarnaan gram bakteri } \\ \text { bervariasi dengan tipe elevasi raised dan } & \text { endofit disajikan pada Tabel } 2 .\end{array}$

Tabel 2. Karakteristik mikroskopis isolat bakteri endofit dari akar tanaman padi varietas situbagendit

\begin{tabular}{cccc}
\hline \multirow{2}{*}{ Isolat Bakteri } & \multicolumn{3}{c}{ Mikroskopis Sel Bakteri } \\
\cline { 2 - 4 } & Bentuk sel & Pewarnaan gram & Endospora \\
\hline EPS1 & Batang & Negatif & Negatif \\
EPS2 & Batang & Positif & Positif \\
EPS3 & Batang & Negatif & Negatif \\
EPS4 & Bulat & Negatif & Negatif \\
\hline
\end{tabular}


Agroradix Vol. 3 No.2

ISSN : 2621-0665

$\begin{array}{rr}\text { Hasil pengamatan } & \text { karakteristik } \\ \text { makroskopis maupun mikroskopis, }\end{array}$ keempat isolat mempunyai karakteristik yang berbeda-beda baik secara morfologi sel bakteri maupun perwarnaan gram. Pengamatan yang dilakukan dengan pewarnaan gram sel bakteri menggunakan zat warna kristal violet sebagai warna primer dan safranin sebagai warna tandingan. Dari hasil pewarnaan gram diperoleh tiga isolat merupakan bakteri gram negatif dan satu isolat merupakan bakteri gram positif dengan bentuk koloni sebagian besar yaitu mempunyai bentuk basil (batang). Pewarnaan gram bakteri berperan untuk melihat perbedaan bentuk sel bakteri dan untuk mengelompokkan bakteri tersebut ke dalam bakteri gram positif dan gram negatif (Lay, 1994). Bentuk sel bakteri yang bermacam-macam terjadi disebabkan pengaruh lingkungan yang tidak mendukung. Umur dan syarat pertumbuhan bakteri yaitu suhu dan nutrisi juga dapat menjadi faktor yang mempengaruhi bentuk sel bakteri. (Ilyas, 2001).

Berdasarkan perbedaan karakteristik makroskopis dan mikroskopis masing-masing isolat diatas, kemudian uji fisiologis dilakukan dan hasilnya disajikan pada Tabel 3. Uji fisiologis adalah tahap yang sangat diperlukan dalam proses identifikasi, karena pengamatan secara makroskopis maupun mikroskopis tidak dapat menentukan jenis bakteri secara spesifik, hal tersebut dikarenakan setiap jenis bakteri mempunyai kemampuan dalam menghasilkan metabolit sekunder atau menggunakan media sebagai sumber karbonnya yang dapat mempengaruhi warna pada reagen test (Lay, 1994).

Tabel 3. Karakteristik fisiologis hasil uji TSIA (Triple Sugar Iron Agar), MR-VP (Methyl RedVoges Proskauer), SCA (Simmon Citrate Agar), motilitas, katalase

\begin{tabular}{|c|c|c|c|c|c|c|c|c|c|c|}
\hline \multirow{2}{*}{$\begin{array}{l}\text { Nama } \\
\text { Isolat }\end{array}$} & \multicolumn{4}{|c|}{ Uji TSIA } & \multirow{2}{*}{ MR } & \multirow{2}{*}{ VP } & \multicolumn{2}{|c|}{ Uji Motilitas } & \multirow{2}{*}{$\begin{array}{c}\text { Uji } \\
\text { Ktls }\end{array}$} & \multirow{2}{*}{ Uji St } \\
\hline & Slant & Butt & Gas & H2S & & & Motil & Indol & & \\
\hline EPS 1 & Merah & Kuning & - & - & - & + & + & + & + & + \\
\hline EPS 2 & Merah & Kuning & - & - & + & - & + & + & + & + \\
\hline EPS 3 & Merah & Kuning & - & - & - & + & + & + & + & + \\
\hline EPS 4 & Merah & Kuning & + & - & + & + & + & + & + & + \\
\hline
\end{tabular}

Berdasarkan uji fisiologis yang ditunjukkan pada Tabel 3 keempat isolat bakteri endofit dapat menggunakan sitrat sebagai salah satu sumber karbonnya. Menurut Luo et al., (2010), setiap tanaman memiliki bakteri endofit yang berbedabeda, hal ini dikarenakan tanaman bisa menerima bakteri yang mempunyai genotif spesifik. Dari hasil pengamatan yang diperoleh secara makroskopis, mikroskopis, dan fisiologis, maka dapat dilakukan proses identifikasi dengan menggunakan buku panduan Bergey's Manual Determination untuk mengetahui jenis genus dari keempat isolat yang berhasil diisolasi. Hasil identifikasi keempat isolat bakteri endofit yang berhasil diisolasi yaitu didapatkan bahwa EPS1 adalah genus dari Pseudomonas, isolat EPS2 adalah genus dari Bacillus, isolat EPS3 adalah genus Enterobacter, isolat EPS4 adalah salah satu spesies dari genus Azotobacter.

\section{Hasil Uji Sinergisme}

Pada metode sterak isolat EPS4 dilihat sifat sinerginya terhadap isolat EPS1, EPS2, dan EPS3. Sedangkan untuk metode kedua dengan paper disc isolat EPS2 dilihat sifat sinerginya terhadap isolat EPS1, EPS3, dan EPS4. Berdasarkan uji sinergisme bakteri endofit yang berhasil diisolasi baik pada metode streak dan metode paper disc hasil menunjukkan 
Agroradix Vol. 3 No.2

ISSN : 2621-0665

isolat bakteri dapat bersinergi atau kompatibel satu dengan yang lain setelah diinkubasi selama 24 jam pada suhu $30^{\circ} \mathrm{C}$. Hasil tersebut ditunjukkan pada Gambar 2 yaitu antara isolat EPS4 dengan isolat EPS1, isolat EPS4 dengan isolat EPS2, dan isolat EPS4 dengan isolat EPS3 tidak membentuk zona hambat atau zona bening. Kesesuaikan atau adanya sifat sinergis dari dua bakteri atau lebih adalah faktor yang sangat diperlukan bakteri tersebut untuk dapat bekerjasama dengan baik. Apalagi jika dalam konsorsium biofertilizer sifat sinergi sangat diperlukan untuk dapat mendukung pertumbuhan suatu tanaman tanpa adanya sifat antagonisme dalam konsorsium tersebut, karena konsorsium tersebut akan memproduksi senyawa yang saling mendukung dan bekerja sama satu dengan yang lain (Arora, 2015).
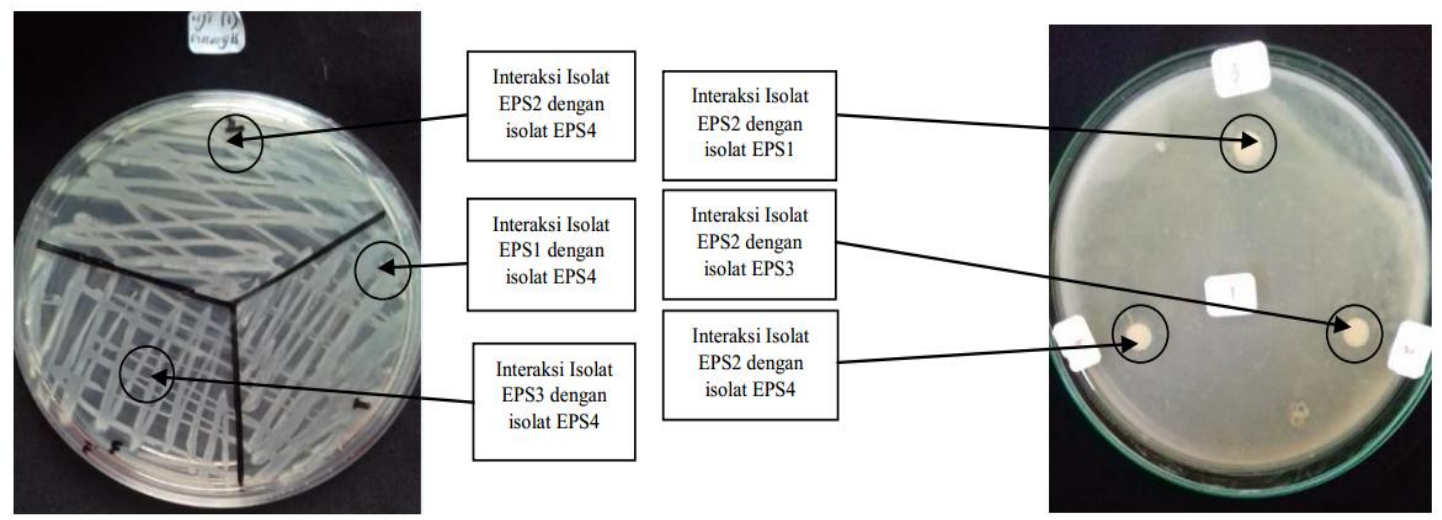

Gambar 2. Hasil uji sinergisme pada keempat isolat yang diujikan

Pada metode lain yaitu dengan menggunakan paper disc untuk menguji sinergisme antar isolat juga menunjukkan adanya hubungan sinergisme. Tidak ada satupun bakteri yang menghambat pertumbuhan bakteri lainnya. Hal ini ditunjukkan dengan tidak terbentuknya zona hambat di sekitar paper disc. Hasil penelitian Asri dan Zulaikah (2016) yang melakukan uji sinergisme antar isolat Azotobacter juga menunjukkan tidak adanya zona hambat atau zona bening pada media pertumbuhan yang digunakan.

Ada beberapa faktor yang mempengaruhi terjadinya proses sinergisme pada isolat bakteri yaitu kemungkinan salah satu genus bakteri dapat menyediakan nutrisi yang dibutuhkan oleh genus bakteri lainnya, hal lain dapat juga terjadi karena salah satu anggota genus bakteri melakukan perlindungan terhadap genus bakteri lain dari bahan yang bersifat toksik yang dapat menurunkan laju pertumbuhan bakteri tersebut, bahkan bisa terjadi karena salah satu anggota genus bakteri tidak mampu melakukan degradasi bahan organik tertentu sehingga akan bergantung pada genus bakteri lain yang mampu mendegradasi bahan organik tersebut (Deng dan Wang, 2016)

\section{SIMPULAN}

Terdapat 4 jenis bakteri endofit pada tanaman padi (Oryza sativa L.) varietas situbagendit yaitu isolat EPS1 adalah genus Pseudomonas, isolat EPS2 adalah genus Bacillus, isolat EPS3 adalah genus Enterobacter, dan isolat EPS4 adalah genus Azotobacter. Keempat isolat bakteri endofit yang ditemukan bersifat sinergis satu sama lain yang ditunjukkan tidak adanya zona hambat yang terbentuk pada media. 
Agroradix Vol. 3 No.2

ISSN : 2621-0665

\section{DAFTAR PUSTAKA}

Asri dan Zulaikah. 2016. Sinergisme Antar Isolat Azotobacter Yang Dikonsorsiumkan. Jurnal Sains dan SenilTS Vol. 5, No.2.

D. Elfiati. 2005. Peranan mikroba pelarut fosfat terhadap pertumbuhan tanaman, Medan: USU).

Etesami, H., Mirsyed, Hosseini, H., Alikhani, H.A., Mohammadi, L. 2014. Bacterial biosynthesis of 1Aminocyclopropane-1Carboxylate (ACC) deaminase and Indole-3Acetic Acid (IAA) as endophytic preferential selection traits by rice plant seedlings. J. Plant. Growth. Regul, h. 1-17.

Ilyas, S. 2001. Mikrobiologi Dasar. Medan: Universitas Sumatera Utara press.

Lay, B.W. 1994. Analisa Mikroba di Laboratorium. Edisi pertama. Cetakan pertama. Jakarta: PT Raja Grafindo Persada.

Luo, S., Wan, Y., Xiao, X., Guo, H., Chen, L., Xi Q, Zeng G., Liu C., Chen, J. 2010. Isolation and Characterization of Endophytic Bacterium LREO7 from Solarium nigrum L., Cadmium Hyperaccumulatorand its potential for Reemediation. Applied Microbiology and Biotechnology, Vol. 89, h. 16371644.

Mbai, F.N., Magiri, E.N., Matiru, V.N., Ng'ang'a, J., Nyambati, V.C.S. 2013. Isolation and Characterisation of Bacterial Root Endophytes with Potential to Enhance Plant Growth from Kenyan Basmati Rice, American International Journal of
Contemporary Research, Vol. 3, No.4.

N. K. Arora. 2015. Plant microbes symbiosis: Applied facets, India: Springer.

Nautiyal, C.S. 1999. An efficient microbiological growth medium for screening phosphate solubilizing microorganisms. FEMS Microbiol. Lett., Vol. 170, h. 265-270.

Nurmayulis. 2005. Pertumbuhan dan Hasil Tanaman Kentang (Solanum tubernosum L.) yang Diberi Pupuk Organik Difermentasi, Azospirillum sp., dan Pupuk Nitrogen di Pangalengan Cisarua. Bandung: Magister IImu Pertanian Pascasarjana Universitas Padjadjaran Bandung

S. Siahaan, M. Hutapea, dan R. Hasibuan. 2013. Penentuan kondisi optimum suhu dan waktu karbonasi pada pembuatan arang dari sekam padi.", Jurnal Teknik Kimia USU.. Vol. 2 No. 1.

Saraswati, R, Prihatini, T dan Hastuti, R.D. 2004. Teknologi Pupuk Mikroba Untuk Meningkatkan Efisiensi Pemupukan dan Keberlanjutan Sistem Produksi Padi Sawah.

Silitonga, D.M., N. Priyani, I. Nurwahyuni. 2008. Isolasi dan Uji Potensi Isolat bakteri Pelarut Fosfat dan Bakteri Penghasil Hormon IAA (Indole Acetic Acid) Terhadap Pertumbuhan Kedelai (Glicine max L.) Pada Tanah Kuning. Medan: Departemen Biologi, Fakultas MIPA, USU.

Simarmata R, Lekatompessy S, Sukiman H. 2007 Isolasi mikroba endofitik dari tanaman obat sambung nyawa (Gymura procumbens) dan 
Agroradix Vol. 3 No.2

ISSN : 2621-0665

analisis potensinya sebagai antimikroba. Berk Penel Hayati; (13):85-90.

Thakuria D, Talukdar NC, Goswami C, Hazarika S, Boro RC, Khan MR. 2004. Characterization and screening of bacteria from the rhizosphere of rice grown in acidic soils of Assam. Curr. Sci. 86: 978985.

Y. Deng, dan S. Y. Wang. 2016. Synergistic growth in bacteria depends on substrate complexity. J Microbiol. 54(1): 23-30. 